\title{
GENETIC DIVERSITY OF AZOTOBACTER STRAINS ISOLATED FROM SOILS BY AMPLIFIED RIBOSOMAL DNA RESTRICTION ANALYSIS
}

\author{
Z. MAZINANI ${ }^{1}$, A. ASGHARZADEH ${ }^{2}$ \\ ${ }^{1}$ Department of Biotechnology, Science and Research Branch, Islamic Azad University, Tehran, Iran \\ ${ }^{2}$ Department of Soil Biology, Soil and Water Researches Institute, Karaj, Iran \\ E-mail: z.mazinani@srbiau.ac.ir
}

\begin{abstract}
Strains of Azotobacter mediate in the nitrogen fixation process by reducing of $\mathrm{N}_{2}$ to ammonia. In this study, 50 strains were isolated from different rhizospheric soil in central Iran, by using soil paste-plate method. These strains were biochemically identified and characterized on differential $L G$ medium based on morphological and physiological properties. Results obtained showed that identified strains were belonging to three species, namely A. chroococcum, A. vinelandii and $A$. beijernckii. In order to molecular analysis, the $16 S$ rRNA gene was amplified using $27 f$ and 1495 r primers and $P C R$ products were subsequently digested with RsaI, HpaII and HhaI. Cluster analysis based on amplified ribosomal DNA restriction analysis were revealed intraspecific polymorphism and differentiated strains into two mains clusters, clusters $A$ and B. Cluster A strains were related to the $A$. vinelandii, whereas cluster $B$ strains were related to the A. chroococcum and A. beijerinckii. The results show that amplified ribosomal DNA restriction analysis is a powerful and discriminatory tool for the identification of members of the genus Azotobacter.
\end{abstract}

Key words: Azotobacter, cluster analysis, nitrogen fixation, $16 S$ rRNA gene, ARDRA.

Introduction. Among the soil bacteria, Azotobacter is remarkable due to the ability to nitrogen fixation. The process comprises the reduction of $\mathrm{N}_{2}$ to ammonia [1].

Azotobacter is one of the members of Azotobacteraceae family, from $\gamma$-subclass proteobacteria, which is capable of fixing atmospheric nitrogen [2]. This bacterium can fix at least $10 \mathrm{mg} \mathrm{N}$ per gram of carbohydrate. The ecological distribution of $\mathrm{AzO}$ tobacter spp. is a complicated subject and is related with diverse factors, which determine the presence or absence of this bacterium in a specific soil. It has been shown that the soil characteristics and climate conditions affect the distribution of this; it includes organic matter content, moisture, $\mathrm{C} / \mathrm{N}$ relation and $\mathrm{pH}[3]$.

Molecular phylogenetic analysis of $16 \mathrm{~S}$ rRNA gene has indicated that the Azotobacter consist of seven species, namely $A$. chroococcum, $A$. vinelandii, A. beijerinckii, $A$. paspali, $A$. armeniacus, $A$. nigricans and $A$. salinestris $[4,5]$.

(c) Z. MAZINANI, A. ASGHARZADEH, 2014
Azotobacters are found in many environments such as soil, water, surfaces of roots and leaves. Furthermore, some species appear in the tropical and polar regions. Their frequency is different in various soils. They are frequent in neutral to alkaline soils and rarely found in acidic soils [6].

The other beneficial effects include the ability to produce exopolysaccharides [7], and antagonism against phytopathogenic microorganisms by production of siderophores, antibiotics and hydrogen cyanide, solubilization of mineral phosphates [1] and capability to synthesize of phytohormones [3].

The analysis of soil microbial diversity is relevant to define soil quality. Polyphasic taxonomical studies, which include phenotypic, genetic and phylogenetic information, have been widely used techniques such as gene sequencing and restriction fragment length polymorphism (RFLP) have been used. The sequence of the $16 \mathrm{~S}$ rRNA gene has beeb widely used as phylogenetic marker in microbial ecology, since the extent of divergence in the sequence of this gene provides an estimate of the phylogenetic distance existing between different species [8]. RFLP is used to identify the difference of DNA fragment length (polymorphism) by digesting with restriction enzymes. RFLP analysis on $16 \mathrm{~S}$ rRNA gene or amplified ribosomal DNA restriction analysis (ARDRA) is a useful technique for genotype identification, to infer genetic variability and similarity of microorganisms [9].

The present study, was performed in order to analyze Azotobacter diversity in the different cultivated regions of central Iran that has not been reported previously. Bacterial strains were first isolated from soil and then identified by amplified ribosomal DNA restriction analysis (ARDRA), both to detect the species variability and to exhibit the potential of ARDRA technique for characterization and differentiation of Azotobacter at the genus and species levels.

Materials and method. Soil sampling. In the present study, soil samples were collected both from different cultivated and uncultivated regions in central 
Iran. Soil samples, were taken at a depth of $10-30 \mathrm{~cm}$ below the surface, and transported from the field to the laboratory in sterile vials. All soil samples were sieved (4-mm-mesh size) to remove stone and small soil particles, and $\mathrm{pH}$ contents determined using $\mathrm{pH}$ meter.

Isolation and identification of Azotobacter strains. Isolation of Azotobacter was performed using the soil paste-plate method [1]. According to this method, about $30-50 \mathrm{~g}$ of each soil sample is mixed with about $0.5-1.0 \mathrm{~g}$ of mannitol, $0.5 \mathrm{~g}$ of $\mathrm{CaCO}_{3}, 0.12 \mathrm{ml}$ of $10 \%$ aqueous $\mathrm{K}_{2} \mathrm{HPO}_{4}$ solution, $0.12 \mathrm{ml}$ of $10 \%$ aqueous $\mathrm{MgSO}_{4}$ solution. Some extra distilled water is also added in order to obtain a soil paste. The soil paste was transferred into a plate, and the surface of the soil was nearly smoothed with a sterile spatula. The samples wereincubated at 27$30{ }^{\circ} \mathrm{C}$ for 7 days. Brown, glistening, slimy Azotobacter colonies grew on the soil surface. Subsequently, brown spots of soil paste surface were placed on Jensen's medium containing (per 1): 20 g sucrose, $1 \mathrm{~g} \mathrm{~K}_{2} \mathrm{HPO}_{4}, 0.5 \mathrm{~g} \mathrm{MgSO}_{4} \cdot 7 \mathrm{H}_{2} \mathrm{O}, 0.5 \mathrm{~g}$ $\mathrm{NaCl}, 0.1 \mathrm{~g} \mathrm{~K}_{2} \mathrm{SO}_{4}, 0.005 \mathrm{~g} \mathrm{Na}_{2} \mathrm{MoO}_{4}, 20 \mathrm{~g}$ agar and $50 \mathrm{mg}$ cycloheximide as the fungal growth inhibitors with $\mathrm{pH}$ 6.9. Azotobacter-like colonies were growth after three-days incubation at $27-30{ }^{\circ} \mathrm{C}$, and were purified by repeated streaking on the same medium. After subculturing, pure strains were selected assuming biochemical characteristics as described in Bergey's Manual of Determinative Bacteriology [4]. Strains were cultured in order to colony morphology, growth ability, pigment production and acid production on $\mathrm{N}$-free LG medium [10] containing bromothymole blue as $\mathrm{pH}$ indicator. The isolated strains were used for DNA extraction. All the strains were stored at $-80{ }^{\circ} \mathrm{C}$ in the $\mathrm{LG}$ broth medium with $50 \%(\mathrm{w} / \mathrm{v})$ glycerol.

Total DNA extraction. Extraction of total genomic DNA was carried out by alkaline lysis method [11]. The strains were cultured on the nutrient agar at $28{ }^{\circ} \mathrm{C}$ for two days. A loop full of cell was suspended in $100 \mu \mathrm{l}$ of sterilized ultrapure water. $100 \mu \mathrm{l}$ of $0.05 \mathrm{M} \mathrm{NaOH}$ was added to every above suspension and was inverted for two minutes. The cell suspension was boiled in water for $15 \mathrm{~min}$ and centrifuged for $2 \mathrm{~min}$ at $13000 \mathrm{rpm}$. Finally, the supernatant was transferred to a new sterile tube and was stored at $-20{ }^{\circ} \mathrm{C}$ for following usage.

Amplified ribosomal DNA restriction analysis (ARDRA). The universal primers 27f and 1495r [12] were used for PCR amplification of 16S rRNA gene, which allowed the amplification of an approximate $1500 \mathrm{bp}$ fragment. PCR amplification was carried out in $25 \mu \mathrm{l}$ reaction volume containing $2.5 \mu \mathrm{l} \mathrm{PCR}$ buffer $(10 \times), 2.5 \mu \mathrm{l}$ dNTPs $(2 \mathrm{mM}), 0.5 \mu \mathrm{l}$ of each primer $(5 \mu \mathrm{M})$ (purchased from MWGH-Biotech, Ebersberg, Germany), $0.5 \mu \mathrm{l}$ Taq DNA polymerase $\left(1 \mathrm{U} \mu \mathrm{l}^{-1}\right), 17.5 \mu \mathrm{l}$ sterile MilliQ water and $1.0 \mu \mathrm{DNA}$ as template $\left(50 \mu \mathrm{g} \mathrm{ml}^{-1}\right)$. The PCR program was carried out under the following condition: $94{ }^{\circ} \mathrm{C}$ for 4 min followed by 35 cycles of amplification $(1 \mathrm{~min}$ of denaturation at $95^{\circ} \mathrm{C}, 1 \mathrm{~min}$ of annealing $62{ }^{\circ} \mathrm{C}$, 2 min of extension at $72^{\circ} \mathrm{C}$ ). After the final cycle, the amplification was extended for $15 \mathrm{~min}$ at $72^{\circ} \mathrm{C}$. All PCR reactions were repeated at least three times in order to confirm the results. $10 \mu$ of each PCR product were separated on $1.5 \%(\mathrm{w} / \mathrm{v})$ agarose gel, in the $1 \times$ buffer $(0.09 \mathrm{M}$ Tris base, $0.09 \mathrm{M}$ sodium borate, $2.5 \mathrm{mM}$ EDTA, pH 8.3) for $1 \mathrm{~h}$ at $85 \mathrm{~V}$. A $10 \mu$-aliquots of the PCR product were digested with $5 \mathrm{U}$ of restriction endonucleases [13] RsaI, HpaII and HhaI (MBI Fermentas), at $37{ }^{\circ} \mathrm{C}$ for $5 \mathrm{~h}$ in a final volume of $30 \mu \mathrm{l}$, as recommended by the manufacturer. The digests were run by electrophoresis on $2.5 \%(\mathrm{w} / \mathrm{v})$ agarose gels in $1 \times$ TBE buffer for $2.5 \mathrm{~h}$ at $75 \mathrm{~V}$. The gels were stained in ethidium bromide $(0.1 \%)$ for $30 \mathrm{~min}$, and restriction patterns were visualized with UV-transilluminator and photographed on a thermal paper type UPP 110S. For normalization of fragments, a $50 \mathrm{bp}$ DNA size marker was used («Amersham», Sweden) and analyzed with UVIDoc software version 99.02.

Statistical analyses of ARDRA patterns. Restricted fragments greater than $50 \mathrm{bp}$ were scored in the binary data matrix form, assuming the presence (1) or absence ( 0 ) of each band. The similarities between patterns of the band were calculated by using Simple Matching correlation coefficient, and the cluster was constructed using the unweighted pair group method with arithmetic mean (UPGMA) [14] clustering along with the NTSYS-PC software version 2.02 [15].

The genetic diversity $(H)$ was calculated using the Shannon-Weaver index

$$
H=-\sum_{i=0}^{n}\left(\left(\frac{x_{i}}{x_{0}}\right) \ln \left(\frac{x_{i}}{x_{0}}\right)\right),
$$

where $H$ is the genetic diversity, $x_{\mathrm{i}}$ was referred to the number of strains in each group, and $x_{0}$ was indicated to the total number of strains [16]. 
Results. Soil sampling. Since presence of Azotobacter in the soil is highly influenced by the $\mathrm{pH}$ value, and their populations increase in soils with $\mathrm{pH}$ above $6.5[6,17], \mathrm{pH}$ values of soil samples collected measured that showed $\mathrm{pH}$ values within the range 7.0-8.5 and were therefore used for Azotobacter isolation (Table 1).

Isolation and identification of strains. Colonies were represented the appearing of brown, glistening and slimy on the soil paste surface after they were incubated for 3-7 days and were purified on the Jensen's medium. Afterwards, the strains were studied based on morphological, biochemical, microscopical characterization $[4,18,19]$, and culture through the LG medium [20]. The strains could grow in LG medium, and dark brown and yellowgreen colonies were formed on the medium. The biochemical studies revealed that all 50 strains of genus Azotobacter could grow in a nitrogen-free medium. Becking [1] showed that Azotobacter spp. fix molecular nitrogen in a nitrogen-free or nitrogen-poor medium in air, but also under reduced oxygen pressure. Cyst formation was tested on Azotobacter strains. As expected, cysts are formed in older cultures grown with sugar as carbon source. Tchan et al. [2] observed that in some species, a medium containing butan-1-ol as organic substrate $(0.1-0.2 \mathrm{ml}$ is added prior to pouring of the agar plates) increases cyst formation. As showed (Table 2) oxidase activity and nitrate reduction was exhibited by strains of Azotobacters. A. chroococcum and $A$. vinelandii strains were positive for motility whereas negative for $A$. beijerinckii. Comparison of the carbon source utilized by the strains showed that all 50 strains studied similarity $>90 \%$ to the genus Azotobacter. All strains utilized glucose, man-

Table 1. Soil samples utilized for the isolation of Azotobacter

\begin{tabular}{|c|c|c|c|c|c|c|c|}
\hline $\begin{array}{c}\text { Soil } \\
\text { number }\end{array}$ & $\begin{array}{l}\text { Sampling } \\
\text { site }\end{array}$ & $\begin{array}{c}\text { Soil } \\
\text { texture }\end{array}$ & $\mathrm{pH}$ & $\begin{array}{c}\text { Soil } \\
\text { number }\end{array}$ & $\begin{array}{l}\text { Sampling } \\
\text { site }\end{array}$ & $\begin{array}{c}\text { Soil } \\
\text { texture }\end{array}$ & $\mathrm{pH}$ \\
\hline 1 & Wheat cultured soil & Clayey & 7.47 & 26 & Maize cultured soil & Clayey & 7.96 \\
\hline 2 & Wheat cultured soil & Clayey & 7.71 & 27 & Maize cultured soil & Clayey & 7.69 \\
\hline 3 & Wheat cultured soil & Clayey & 7.41 & 28 & Wheat cultured soil & Clayey & 7.46 \\
\hline 4 & Wheat cultured soil & Clayey & 7.16 & 29 & Wheat cultured soil & Clayey & 7.74 \\
\hline 5 & Barely cultured soil & Clayey & 7.04 & 30 & Wheat cultured soil & Clayey & 7.21 \\
\hline 6 & River bank & Silt & 8.08 & 31 & Wheat cultured soil & Clayey & 7.91 \\
\hline 7 & Wheat cultured soil & Clayey & 7.63 & 32 & Maize cultured soil & Clayey & 7.30 \\
\hline 8 & Wheat cultured soil & Clayey & 7.88 & 33 & Wheat cultured soil & Clayey & 7.42 \\
\hline 9 & Wheat cultured soil & Clayey & 7.41 & 34 & Wheat cultured soil & Clayey & 7.50 \\
\hline 10 & Rural street borders & Clayey & 7.97 & 35 & Wheat cultured soil & Clayey & 8.43 \\
\hline 11 & River bank & Silt & 8.26 & 36 & River bank & Silt & 8.11 \\
\hline 12 & Wheat cultured soil & Clayey & 7.94 & 37 & Wheat cultured soil & Clayey & 7.42 \\
\hline 13 & Rural street borders & Clayey & 8.01 & 38 & Maize cultured soil & Clayey & 7.53 \\
\hline 14 & Wheat cultured soil & Clayey & 7.04 & 39 & Maize cultured soil & Clayey & 8.22 \\
\hline 15 & Maize cultured soil & Clayey & 7.19 & 40 & Maize cultured soil & Clayey & 7.35 \\
\hline 16 & River bank & Sandy & 8.44 & 41 & Wheat cultured soil & Clayey & 7.87 \\
\hline 17 & River bank & Sandy & 8.38 & 42 & Maize cultured soil & Clayey & 8.34 \\
\hline 18 & Wheat cultured soil & Clayey & 7.21 & 43 & Maize cultured soil & Clayey & 7.75 \\
\hline 19 & Barely cultured soil & Clayey & 7.42 & 44 & Maize cultured soil & Clayey & 8.12 \\
\hline 20 & Wheat cultured soil & Clayey & 7.53 & 45 & Maize cultured soil & Clayey & 8.34 \\
\hline 21 & Wheat cultured soil & Clayey & 7.63 & 46 & Barely cultured soil & Clayey & 7.36 \\
\hline 22 & Wheat cultured soil & Clayey & 7.17 & 47 & Barely cultured soil & Clayey & 7.46 \\
\hline 23 & Wheat cultured soil & Clayey & 7.05 & 48 & Barely cultured soil & Clayey & 7.64 \\
\hline 24 & Wheat cultured soil & Clayey & 8.44 & 49 & Barely cultured soil & Clayey & 7.33 \\
\hline 25 & Wheat cultured soil & Clayey & 7.31 & 50 & Barely cultured soil & Clayey & 7.48 \\
\hline
\end{tabular}


nitol and benzoate as carbon substrates, but some utilized malonate, caproate, inositol, rhamnose, starch, trehalose, caprylate and glycolate. So, many variations did occur among these strains in utilizing some of the carbon sources. Related to this, the 50 strains were selected that belong to Azotobacter genus. Among these strains, 23 were identified as $A$. chroococcum, 17 as $A$. vinelandii and 10 as $A$. beijerinckii (Table 2). However, our findings showed that populations of the other Azotobacter species might be low in rhizosphere, so they could not be isolated and identified with the procedure used.

ARDRA and data analysis. The 16S rRNA genes of 50 strains were PCR amplified using the universal primers of $27 \mathrm{f}$ and $1495 \mathrm{r}$ and produced a $1500 \mathrm{bp}$ fragment. The endonucleases of RsaI, HpaII and HhaI were employed for digestion of PCR products, and minor divergent restriction patterns were generated, were selected based on the experiments previously performed by Aquilanti et al. [13]. The size of digested fragments obtained of each enzyme were summed up together and compared with the size of the undigested fragments $(1500 \mathrm{bp})$. A little difference was observed due to production of restriction fragments smaller than $50 \mathrm{bp}$ that are undetectable.

The analysis of restriction patterns generated by ARDRA revealed different bands within Azotobacter spp. strains. According to the outcomes obtained, 2, 5 and 9 different restriction patterns were produced for RsaI, HpaII and HhaI, respectively. The restriction patterns obtained of each enzyme were entitled by small letters (Table 3 ). The restriction patterns were used for classification of strains into 16 different ribogroups. The tested strains, belonged to three species $A$. chroococcum, A. vinelandii and A. beijerinckii which were called abbreviately Ac, $\mathrm{Av}$ and $\mathrm{Ab}$, respectively. The presence of a large number of polymorphic bands, when using the same endonucleases demonstrates that there are differences within the sequence of the 16S rRNA gene and therefore, there is a large genetic diversity in the tested bacterial strains. This showed that the same pattern in the restriction profiles obtained

Table 2. Differential characteristics of the Azotobacter species used in this work were taken from $[1,11,13]$

\begin{tabular}{lcccc}
\hline \multicolumn{1}{c}{ Characteristics } & A. chroococcum & A. vinelandii & A. beijerinckii \\
\hline Number of strains & 23 & 17 & 10 \\
Colony morphology & $\begin{array}{l}\text { Small, transparent, circular, } \\
\text { slimy, dark-brown }\end{array}$ & $\begin{array}{c}\text { Small, transparent, circular, } \\
\text { slimy, yellow-green }\end{array}$ & $\begin{array}{c}\text { Small, transparent, circular, } \\
\text { slimy, dark-brown }\end{array}$ \\
Cell shape & Rod & Rod & Rod \\
Gram reaction & - & - & - \\
Motility & + & + & - \\
Cysts & + & + & + \\
Growth on N2 free medium & + & + & + \\
Oxidase activity & + & + & + \\
Nitrate reduction & + & + & + \\
Carbon sources utilization & + & + & + \\
glucose & + & + & + \\
malonate & + & + & - \\
mannitol & + & + & + \\
caproate & + & + & - \\
inositol & - & + & + \\
rhamnose & - & + & + \\
starch & + & + & + \\
benzoate & + & + & + \\
trehalose & + & + & + \\
caprylate & + & + & + \\
glycolate & + & + & + \\
& & + & + & +
\end{tabular}




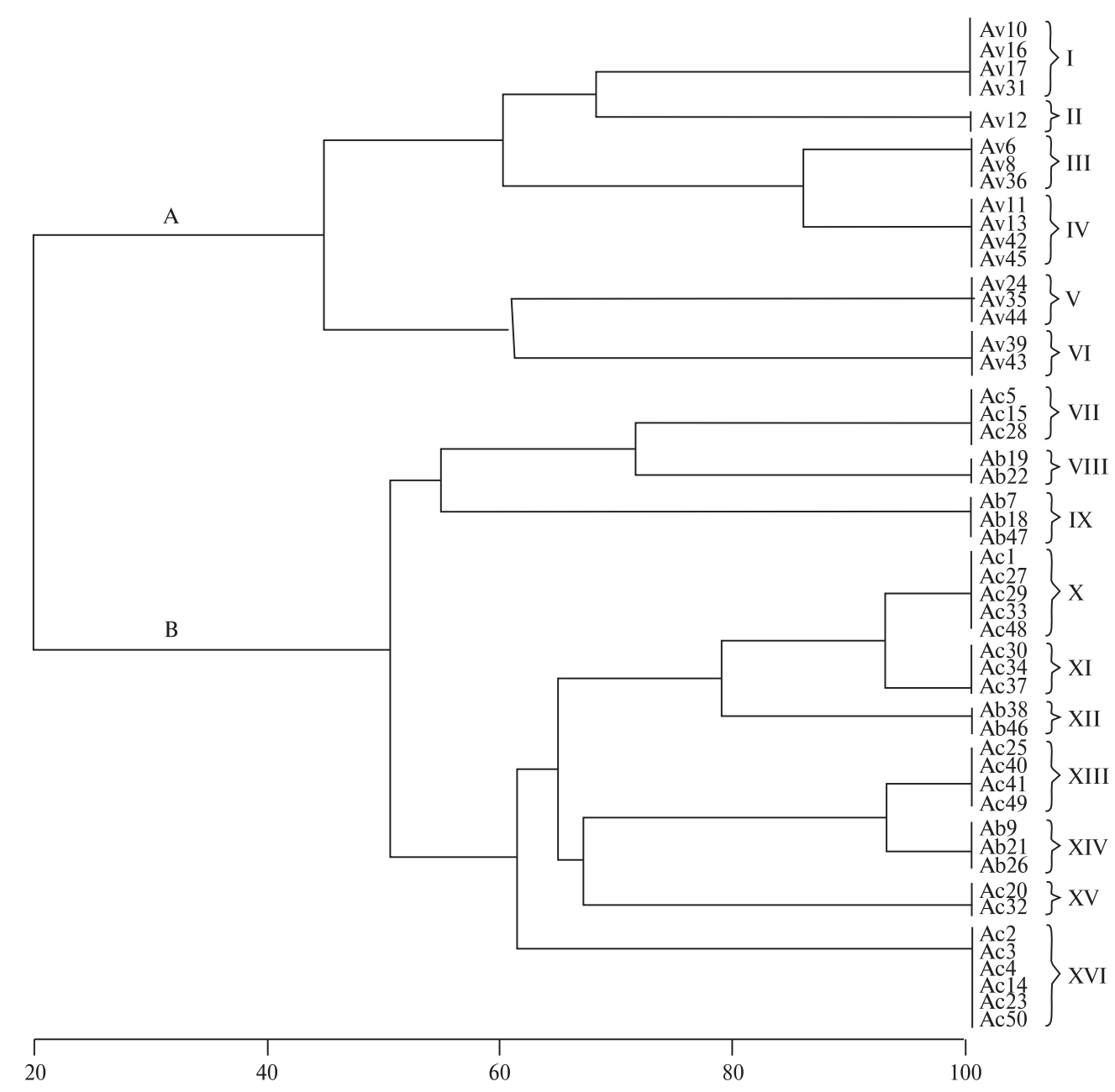

Fig. 1. UPGMA dendrogram of 50 Azotobacter strains isolated from soil, based on ARDRA, representing genetic relationships among strains. This dendrogram comprised two distinct clusters, clusters A and B. The endonucleases used were RsaI, HpaII and HhaI. Ribogroups I to XVI (indicated on the right) are described in Table 2

with the three restriction enzymes had $100 \%$ similarity, thus suggesting that the same strains may belong to the same taxon [8]. Amos and Harwoud [21] mention that there could be many factors related to the genetic diversity in a population, for example, the site of origin of the strains as well plant crops.

Cluster analysis. The obtained dendrogram, showed that the tested strains were placed in two main clusters based on a genetic distance of 0.4

The cluster A comprised 17 strains of $A$. vinelandii and cluster B comprised 23 strains of $A$. chroococcum and 10 strains of $A$. beijerinckii (Fig. 1). Cluster A included six ribogroups I, II, III, IV, V and VI that included 4, 1, 3, 4, 3 and two strains of $A$. vinelandii, respectively. This cluster comprised
$34 \%$ of the tested strains. Cluster B contained ten ribogroups VII, VIII, IX, X, XI, XII, XIII, XIV, $\mathrm{XV}$ and XVI that ribogroups VII, X, XI, XIII, XV and XVI, including, 3, 5, 3, 4, 2 and 6 strains of A. chroococcum, and ribogroups VIII, IX, XII and XIV, including, 2, 3, 2 and 3 strains $A$. beijerinckii, respectively. This cluster comprised $66 \%$ of the tested strains, which $46 \%$ related to A. chroococcum and $20 \%$ to $A$. beijerinckii.

Among the endonucleases RsaI, HpaII and HhaI, used to identify the $16 \mathrm{~S}$ rRNA genetic variation of the strains, only the enzyme HhaI could discriminate the strains, while the other two endonucleases produced a low number of restriction patterns. As showed (Fig. 2) the enzyme RsaI produced 
two different restriction patterns. All the present Azotobacter species generated the different restriction pattern $\mathrm{a}_{1}$, while Av12, Av39, Av43, Ac20 and Ac32 generated the restriction pattern $b_{1}$. Therefore it is suggested that RsaI is not suitable to be utilized in the genetic variation study of Azotobacter strains. Restriction analysis of the $16 \mathrm{~S}$ rRNA gene of the Azotobacter strains with HpaII allowed to obtain five different restriction patterns $\left(\mathrm{a}_{2}, \mathrm{~b}_{2}, \mathrm{c}_{2}\right.$, $\left.\mathrm{d}_{2}, \mathrm{e}_{2}\right)$. A. vinelandii strains produced the restriction patterns $\mathrm{a}_{2}$ and $\mathrm{b}_{2}$, while $\mathrm{c}_{2}, \mathrm{~d}_{2}$ and $\mathrm{e}_{2}$ restriction patterns are common to the species $A$. chroococcum and $A$. beijerinckii (Table 3 ).

Results obtained onto studied strains indicate that enzyme HhaI produced a total of nine different restriction patterns $\left(\mathrm{a}_{3}, \mathrm{~b}_{3}, \mathrm{c}_{3}, \mathrm{~d}_{3}, \mathrm{e}_{3}, \mathrm{f}_{3}, \mathrm{~g}_{3}, \mathrm{~h}_{3}\right.$, $\left.\mathrm{i}_{3}\right), 2$ of which, $\mathrm{h}_{3}$ and $\mathrm{g}_{3}$, specific for $A$. beijerinckii (Table 3) and showed the highest level of resolution within the Azotobacter strains. As reported (Table 4) within the strains tested, A. beijerinckii showed the lowest diversity $(H=16.09)$ and the highest level of diversity belonged to $A$. vinelandii and A. chroococcum. It might be supposed that $A$. beijerinckii would favor somewhat acidic soils [1], while the studied soil samples were alkaline.
Discussion. Nitrogen fixation in nature is performed by various groups of microorganisms like Azospirillum, Klebsiella, Enterobacter, Pseudomonas and Bacillus. Documentation of bacterial diversity in rhizosphere is essential because it helps to identify novel bacterial strains capable of nitrogen fixing in a high efficiency.

In this study, 50 Azotobacter strains which belong to three species $A$. chroococcum, A. vinelandii and A. beijerinckii were isolated from soil in regions of central Iran. They were identified by biochemical tests and examined by using the ARDRA analysis.

Amplified ribosomal DNA restriction analysis (ARDRA) is a technique to study 16S rRNA gene fragments that are generated by restriction enzymes. This technique has been utilized for genetic studies and diversity analysis of many bacteria such as Mycobacterium [22], Streptococcus and Enterococcus $[23,24]$

In the present work, we suggest a triphasic method for Azotobacter spp. isolation and identification. The first step was the preparation of soil paste-plate and transferring brown blots obtained on Jensen's medium to be used for isolation of Azotobacter strains of soil. Aquilanti et al. [20] demonstrated that

Table 3. Restriction patterns obtained for the Azotobacter strains isolated from soil by ARDRA, using the restriction enzymes RsaI, HpaII, HhaI

\begin{tabular}{|c|c|c|c|c|}
\hline \multirow{2}{*}{ Strains } & \multicolumn{3}{|c|}{ Restriction patterns } & \multirow{2}{*}{ Ribogroups } \\
\hline & RsaI & HpaII & HhaI & \\
\hline Av10, Av16, Av17, Av31 & $a_{1}$ & $a_{2}$ & $\mathrm{~b}_{3}$ & I \\
\hline Av12 & $b_{1}$ & $a_{2}$ & $a_{3}$ & II \\
\hline Av6, Av8, Av36 & $a_{1}$ & $a_{2}$ & $\mathrm{c}_{3}$ & III \\
\hline Av11, Av13, Av42, Av45 & $a_{1}$ & $b_{2}$ & $a_{3}$ & IV \\
\hline Av24, Av35, Av44 & $a_{1}$ & $b_{2}$ & $b_{3}$ & $\mathrm{~V}$ \\
\hline Av39, Av43 & $\mathrm{b}_{1}$ & $b_{2}$ & $\mathrm{c}_{3}$ & VI \\
\hline Ac5, Ac15, Ac28 & $a_{1}$ & $\mathrm{c}_{2}$ & $\mathrm{~d}_{3}$ & VII \\
\hline $\mathrm{Ab} 19, \mathrm{Ab} 22$ & $a_{1}$ & $e_{2}$ & $\mathrm{~g}_{3}$ & VIII \\
\hline $\mathrm{Ab} 7, \mathrm{Ab} 18, \mathrm{Ab} 47$ & $a_{1}$ & $e_{2}$ & $\mathrm{~h}_{3}$ & IX \\
\hline Ac1, Ac27, Ac29, Ac33, Ac48 & $a_{1}$ & $c_{2}$ & $\mathrm{e}_{3}$ & $X$ \\
\hline Ac30, Ac34, Ac37 & $a_{1}$ & $\mathrm{c}_{2}$ & $\mathrm{f}_{3}$ & $\mathrm{XI}$ \\
\hline Ab38, Ab46 & $a_{1}$ & $\mathrm{e}_{2}$ & $\mathrm{i}_{3}$ & XII \\
\hline Ac25, Ac40, Ac41, Ac49 & $a_{1}$ & $\mathrm{~d}_{2}$ & $\mathrm{~d}_{3}$ & XIII \\
\hline $\mathrm{Ab} 9, \mathrm{Ab} 21, \mathrm{Ab} 26$ & $a_{1}$ & $\mathrm{~d}_{2}$ & $\mathrm{i}_{3}$ & XIV \\
\hline Ac20, Ac32 & $\mathrm{b}_{1}$ & $\mathrm{~d}_{2}$ & $\mathrm{e}_{3}$ & XV \\
\hline Ac2, Ac3, Ac4, Ac14, Ac23, Ac50 & $a_{1}$ & $\mathrm{~d}_{2}^{2}$ & $\mathrm{f}_{3}$ & XVI \\
\hline
\end{tabular}



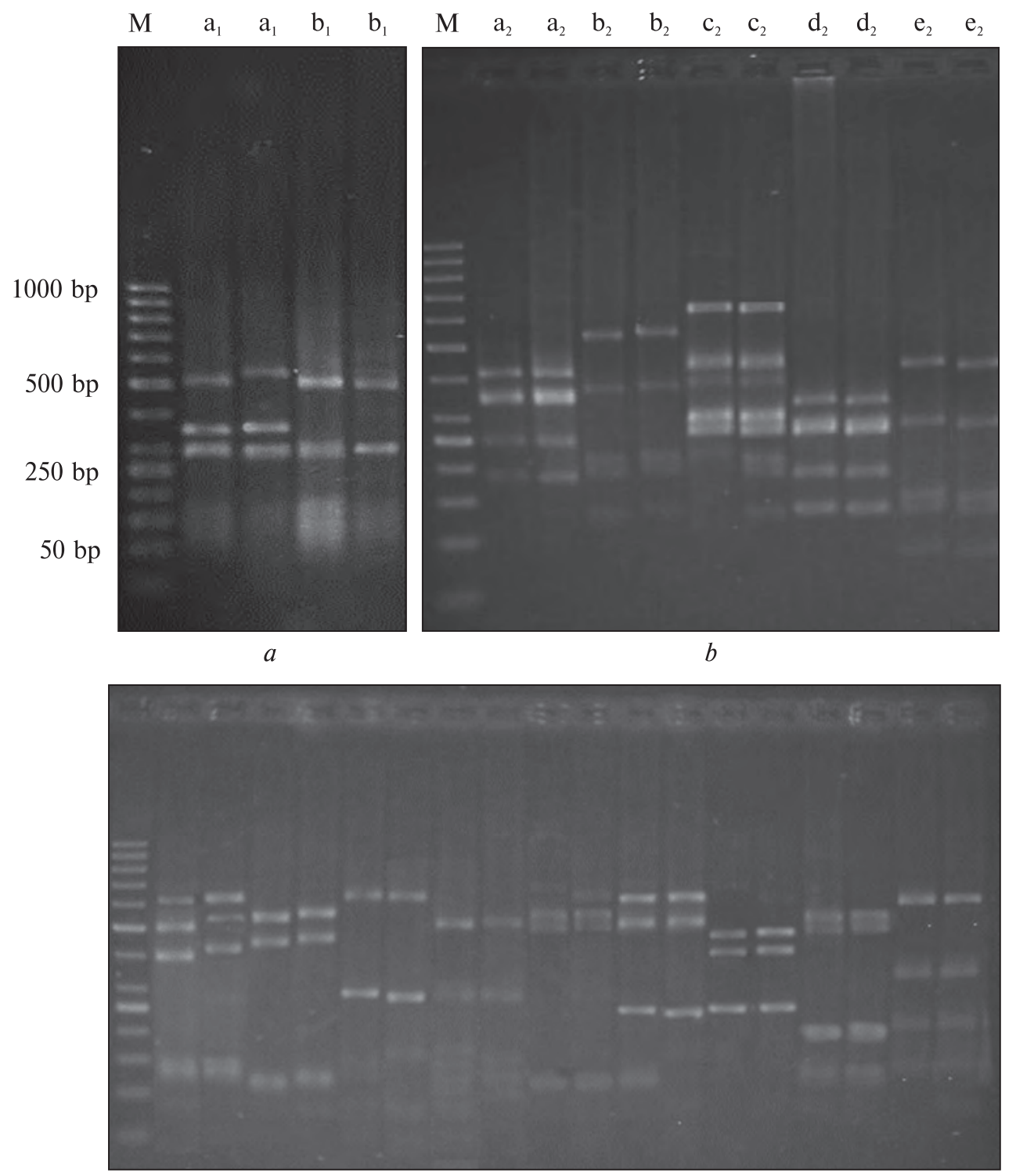

$c$

Fig. 2. Agarose gel electrophoresis of restriction fragments obtained from the digestion of $16 \mathrm{~S}$ rDNA gene of Azotobacter strains: $a$-ARDRA profiles, obtained with the enzyme RsaI; $b$-ARDRA profiles, obtained with the enzyme HpaII; $c$ - ARDRA profiles, obtained with the enzyme HhaI. M -50 base pair ladder

this method is extremely useful for a preliminary screening of soil samples allowing those containing $\mathrm{N}$-fixing bacteria to be recognized and subsequently used for isolation. Moreover, the following streaking and incubation on Jensen's medium [19] permit a rapid individuation of slimy and glistening Azotobacter-like colonies.

At the second step, strains were identified by using biochemical characteristics and culture on differ- ential LG medium in order to observe of morphology, consistency and pigmentation of the colonies. Besides, the presence of a $\mathrm{pH}$ indicator permitted the individuation of the Azotobacter acidifying strains.

At the latter step, results were confirmed by ARDRA, the amplification of 16S rRNA gene using universal primers of belonging to Azotobacter genus and digestion of PCR products with restriction enzymes RsaI, HpaII and HhaI. 
Genetic diversity of Azotobacter strains isolated from soils by amplified ribosomal DNA restriction analysis

Table 4. Genetic diversity calculated based on the Shannon-Weaver index $(H)$ and percentage of species obtained, $\%$

\begin{tabular}{l|c|c|c}
\hline \multicolumn{1}{c|}{ Species } & $H$ & $\%$ & Abbreviation \\
\hline A. chroococcum & 17.86 & 46 & $\mathrm{Ac}$ \\
A. vinelandii & 18.33 & 34 & $\mathrm{Av}$ \\
A. beijerinckii & 16.09 & 20 & $\mathrm{Ab}$ \\
\hline
\end{tabular}

In this study, the digestion of $16 \mathrm{~S}$ rDNA gene of Azotobater strains by RsaI produced 3 to 4 bands for each strain (Fig. 2). Genetic diversity of $A z O-$ tobater strains as showed by this enzyme was very low. The best reason for this condition was that the strains had the same digestion regions in their conserved site.

The use of HpaII and HhaI on strains led to the differentiation between the present Azotobacter species. It is in agreement with the obtained results by Aquilanti et al. [13] and Tiedje et al. [25] which evidenced that HpaII and HhaI gave the greatest differentiation on the basis of phylogenetic analysis of soil microbial communities, and by Moyer et al. [26] which described HhaI as a suitable tool for the detection of bacterial taxa.

However, our results indicated that utilization of RsaI, HpaII and HhaI on Azotobacter strains were not sufficient for their clear identification. It is likely due to the presence of restriction sites on the rRNA gene or to the presence of the gene alleles that are different in sequences and place on a single genome, as reported by Vaneechoutte et al. [27].

This work has also revealed that some strains were closely related and grouped each other as showed in the dendrogram (Fig. 1). Strains in the same restriction patterns according to the ARDRA profile would appear in different groups in this dendrogram. It could be due to the difference of the techniques of analysis. For instance, Av12 and Av31 were closely related to each other as revealed in the dendrogram, but these two strains were different from each other in the restriction profile (Fig. 2). Av12 belongs to the ribogroup II, whereas Av31 belongs to the ribogroup I.

Therefore, we have to study the strains utilized the complete set of enzymes for identify them in terms of cluster analysis and consider whether this molecular technique could reveal the data obtained by ARDRA.
Among the genus Azotobacter, A. chroococcum and $A$. vinelandii clustered at a 0.5 genetic distance. It is in accordance with the result of De Smedth et al. [5] that were indicated $A$. chroococcum and $A$. beijerinckii are the closest species.

When we combined the restriction profiles of RsaI, HpaII and HhaI, further improvement in the resolution and differentiation of genotypes were observed, classifying the 50 isolates into 16 ribogroups. Therefore, the combined analysis of three enzymes disclosed genetic diversity in Azotobacter species. Several authors suggest that detection at the species level using ARDRA performed with a lower number of restriction enzymes (three or fewer) [28-30].

Conclusion. From this study, it can be concluded that the $A$. chroococcum was the prevalent species among species isolated. The DNA of Azotobacters was amplified using universal 16S rRNA gene primers and they were phenotypically identified as $A$. chroococcum, A. vinelandii and A. beijerinckii. Our results showed that the triphasic method is capable of the identification of Azotobacters at the species level and to the reveal and study of the biodiversity. Data from the literature as well as our results disclose that biodiversity of Azotobacter species are clodely related with $\mathrm{pH}$ value.

We would like to express our special gratitude to Dr. M. Khosroshahli (Department of biotechnology) for his helpful support. This work was supported by Islamic Azad University, Science and Research Branch, Tehran, Iran.

ГЕНЕТИЧЕСКОЕ РАЗНООБРАЗИЕ ЛИНИЙ

AZOTOВАСТЕR, ВЫДЕЛЕННЫХ ИЗ ПОЧВ,

НА ОСНОВЕ РЕСТРИКЦИОННОГО

АНАЛИЗА АМПЛИФИЦИРОВАННЫХ

РИБОСОМАЛЬНЫХ ДНК

\section{Z. Mazinania, A. Asgharzadehb}

Штаммы Azotobacter являются посредниками в процессах фиксации азота, восстанавливая $\mathrm{N}_{2}$ до аммония. Из разных ризосферных почв Ирана выделено 50 штаммов. Эти штаммы биохимически идентифицированы и охарактеризованы на дифференциальной среде LG на основе морфологических и физиологических свойств.Полученные результаты показали, что идентифицированные штаммы принадлежат трем видам - A. chroococcum, A. vinelandii и $A$. beijerinckii. Для молекулярного анализа ген $16 \mathrm{~S}$ рРНК был амплифицирован с использованием $27 \mathrm{f}$ и 1495r праймеров, а продукты ПЦР расщеплены 
с помощью RsaI, HpaII и HhaI. Кластерный анализ, основанный на рестрикционном анализе амплифицированных рибосомальных ДНК (ARDRA), показал межвидовой полиморфизм и разделение штаммов на два основных кластера, А и В. Линии кластера А относятся к $A$. vinelandii, а кластера В к $A$. chroococcum и A. beijerinckii. Результаты показывают, что ARDRA является эффективным методом идентификации видов рода Azotobacter.

\section{REFERRNCES}

1.Becking J.H. The family Azotobacteraceae // The Procaryotes : A handbook on habitats, isolation, and identification of bacteria. - Heidelberg : Springer, 1981. - P. 2440.

2. Tchan Y.T., New P.B. Azotobacteraceae // Bergey's manual of systematic bacteriology / Eds N.R. Kreig, J.G. Holt. - Baltimore : Williams \& Wilkins Press, 1984. - P. 220-229.

3. Tejera N., Lluch C., Martinez-Toledo M.V., Gonzalez-Lopez M.V. Isolation and characterization of Azotobacter and Azospirillum strains from the sugarcane rhizosphere // Plant Soil. - 2005. - 270, № 1. P. 223-232.

4. Holt J.G., Krieg N.R., Sneath P.H.A. et al. Bergey's manual of determinative bacteriology. - Philadelphia : Williams and Wilkins Press, 1994. - 787 p.

5. De Smedth J., Bauwens M., Tytgat R., De Ley J. Intra- and intergeneric similarities of ribosomal ribonucleic acid cistrons of free-living, nitrogen-fixing bacteria // Int. J. Syst. Bacteriol. - 1980. - 30, № 1. - P. 106-122.

6. Jensen V., Petersen E.J. Taxonomic studies on Azotobacter chroococcum Beijerinck and Azotobacter beijerinckii Lipman // J. Royal Veterinary and Agricultural College : Yearbook. - 1995. - 84, № 4. P. 107-126.

7. Clementi F. Alginate production by Azotobacter vinelandii // Biotechnology - 1997. - 17, № 4. P. 327-361.

8. Spinosa-Victoria D., Lopez-Reyes L., Cruz-Benitez A.D.L. Use of $16 \mathrm{~S}$ rRNA gene for characterization of phosphate-solubilizing bacteria associated with corn // Articulo Cientiffico. Rev. Fitotec. Mex. - 2009. 32, № 1. - P. 31-37.

9. Bahri S., Wahyudi A.T., Mubarik N. R. Genetic diversity of plant growth promoting rhizobacteria of Bacillus sp. based on 16S rRNA sequence and amplified rDNA restriction analysis // Microbiology. 2009. - 3, № 1. - P. 12-16.

10. Turner G.L., Gibson A.H. Measurement of nitrogen fixation by indirect means // Methods for evaluating biological nitrogen fixation / Ed. F.J. Bergersen. Chichester : Wiley Press, 1980. - P. 111-158.

11. Rademaker J.L.,W. de Bruijin F.J. Characterization and classification of microbes by rep-PCR genomic finger printing and computer-assisted pattern analyse // Int. J. Syst. Evol. Microbiol. - 1997. - 50, № 1. - P. 665-667.

12. Weisburg W.G., Barns S.M., Pelletier D.A., Lane D.J. $16 \mathrm{~S}$ ribosomal DNA amplification for phylogenetic study // J. Bacteriol. - 1991. - 173, № 2. P. 697-703.

13. Aquilanti L., Cavalca L., Clementi F. et al. Amplified ribosomal DNA restriction analysis for the characterization of Azotobacteraceae: a contribution to the study of these free-living nitrogen-fixing bacteria // Microbiol. Meth. - 2004. - 57, № 1. - P. 197206.

14. Sokal R.R., Sneath P.H.A. Principle of Numerical taxonomy. - San Francisco : W.H. Freeman, 1963. $359 \mathrm{p}$.

15. Rohlf F.J. NTSYS-pc. Numerical taxonomy and Multivariate analysis system, Version 1.8 Applied Biostatistics. - New York : Setauket press, 1998. $37 \mathrm{p}$.

16. Shannon C.E., Weaver W. The mathematical theory of communication. - Urbana : Univ. Illinois Press, 1949. - $117 \mathrm{p}$.

17. González-Lypez J. Microorganismos diazotrofos asociados a raíces de plantas no leguminosas. - Madrid : Rueda Press, 1992. - 280 p.

18. García-Esquivel G., Calva-Calva G., Ferrera-Cerrato $R$. et al. Encystment of Azotobacter nigricans grown diazotrophically on kerosene as sole carbon source // Arch Microbiol. - 2009. - 191, № 3. - P. 275281.

19. Ahmad F., Ahmad I., Khan M.S. Screening of freeliving rhizospheric bacteria for their multiple plant growth promoting activities // Microbiol. Res. 2006. - 163, № 1. - P. 173-181.

20. Aquilanti L., Favilli F., Clementi F. Comparison of different strategies for isolation and preliminary identification of Azotobacter from soil samples // Soil Biol. Biochem. - 2004. - 36, № 1. - P. 14751483.

21. Amos W., Harwoud J. Factors affecting levels of genetic diversity in natural population // Biol. Sci. 1998. - 353, № 1366. - P. 177-186.

22. Baere T. D., Mendoca R., Claeys G. et al. Evaluation of amplified rDNA restriction analysis (ARDRA) for the identification of cultured mycobacteria in diagnostic laboratory // BMC Microbiol. - 2002. - 2, № 4. - P. 1-22.

23. Jayarao B.M., Dorer J.R., Oliver S.P. Restriction fragment length polymorphism analysis of $16 \mathrm{~S}$ ribosomal DNA of Streptococcus and Enterococcus species of bovine origin // J. Clin. Microbiol. - 1992. 30, № 9. - P. 2235-2240.

24. Sasaki E., Osawa R., Nishitani Y., Whiley R.A. 
ARDRA and RAPD analysis of human and animal isolates of Streptococcus gallolyticus // J. Vet. Med. Sci. - 2004. - 66, № 11. - P. 1467-1470.

25. Tiedje J.M., Asuming-Brempong S., Nusslein K. et al. Opening the black box of soil microbial diversity // Appl. Soil Ecol. - 1999. - 13, № 2. - P. 109122.

26. Moyer C.L., Tiedje J.M., Dobbs F.C., Karl D.M. A computer-simulated restriction fragment length polymorphism analysis of bacterial small-subunit rRNA genes: efficacy of selected tetrameric restriction enzymes for studies of microbial diversity in nature // Appl. Environ. Microbiol. - 1996. - 62, № 7. P. 2501-2507.

27. Vaneechoutte M., Rossau R., De Vos P. Rapid identification of the Comamonadaceae with amplified ribosomal restriction analysis (ARDRA) // FEMS Microbiol. Lett. - 1992. - 93, № 3. - P. 227-234.
28. Chéneby D., Philippot L., Hartmann A. et al. 16S rRNA gene analysis for characterization of denitrifying bacteria isolated from three agricultural soils// FEMS Microbiol. Ecol. - 2000. - 34, № 2. P. 121-128.

29. Jang J., Bongjoon K., Jongho L. et al. Identification of Weissella species by the genus-specific amplified ribosomal DNA restriction analysis // FEMS Microbiol. Lett. - 2002. - 212, № 1. - P. 29-34.

30. Ventura M., Elli M., Reniero R., Zink R. Molecular microbial analysis of Bifidobacterium isolates from different environments by the species-specific amplified ribosomal DNA restriction analysis (ARDRA) // FEMS. Microbiol. Ecol. - 2001. - 36, № 2. P. 113-121. 